\title{
Effect of Endosulfan (EC 35) on Oxygen Consumption Patterns and Gill Morphology of the Indian Flying Barb, Esomus danricus
}

\author{
Suchismita Das ${ }^{1 *}$ and Abhik Gupta ${ }^{2}$ \\ ${ }^{1}$ Department of Life Science and Bioinformatics, Assam University, Silchar, India (788011) \\ ${ }^{2}$ Department of Ecology and Environmental Science, Assam University, Silchar, India (788011) \\ Accepted 15 December 2012
}

\begin{abstract}
The Indian flying barb, Esomus danricus was exposed to three sub lethal concentrations of endosulfan EC $35\left(0.49,0.049\right.$ and $\left.0.0049 \mu \mathrm{g} \mathrm{l}^{-1}\right)$ to determine changes in the oxygen consumption patterns and gill morphology. The rates of oxygen consumption declined, while the gills showed various histopathological changes including marked epithelial lifting, lamellar fusion, hyperplasia, hypertrophy, mucus secretion, mucous cell proliferation, vascular congestion and blood sinus constriction after 28 days of toxicant exposure. Higher doses of exposure had more severe effects.
\end{abstract}

Key words: organochlorine, sublethal, teleost

\section{INTRODUCTION}

A major part of the total pesticide application in the Assam state in the north eastern region of India is in its tea gardens (Gurusubramanian et al., 2008). The average consumption of pesticides in India is $0.5 \mathrm{~kg} / \mathrm{ha}$. Against this modest figure, pesticide use in tea is $11.5 \mathrm{~kg} / \mathrm{ha}$ in Assam (including the Barak Valley), $16.75 \mathrm{~kg}$ $\mathrm{ha}^{-1}$ in Dooars and Terai, and $7.35 \mathrm{~kg} / \mathrm{ha}$ in Darjeeling (North Bengal) (Gurusubramanian et al., 2008), thereby increasing the risk of pesticide pollution in tea-growing areas. Endosulfan is a broad-spectrum organochlorine pesticide widely used in tea gardens and ricepaddy fields throughout Assam for the control of arthropod pests. From an environmental perspective, endosulfan, a persistent organic pollutant, has high aquatic toxicity and may be toxic to fishes even at recommended levels (Romeo and Quijano, 2000). It is, therefore, very likely that this pesticide enters adjoining water bodies and causes harm to non-target aquatic organisms too. Several studies have indicated that pesticide pollution may occur at higher concentrations in small, shallow ponds (Berrill et al., 1994).

The Indian flying barb, Esomus danricus inhabits shallow water bodies and is a cyprinid that is economically important both as an ornamental and a food fish. It has been identified as an important "small indigenous species (SIS)" that meets the protein requirements of large sections of economically marginalized rural consumers in Bangladesh as well as West Bengal and Assam (Samad et al., 2010). Toxicity assessments of pesticides like endosulfan in Indian cyprinids have mostly been conducted on larger commercially important species such as Labeo rohita (Rao et al., 1980), with very few studies on SIS representatives (Das and Gupta, 2012; Vutukuru et al., 2005). Besides, being an IUCN 'least concern' species (Devi and Boguskaya, 2009) its natural populations face no imminent threat of decimation or extinction, and can be maintained easily in the laboratory as it suffers low mortality and requires limited space. Effects of pollutants on fish have been assessed by many workers using a variety of different approaches including physiological (Capkin et al., 2005), behavioural (Shivakumar and David, 2004), biochemical (Tripathi and Verma, 2004) or hormonal (Thangavel et al., 2010) as well as by gill histopathological (Schwaiger et al., 2004) studies. The rate of oxygen consumption is a common physiological parameter that is used in such experiments (Barbieri, 2007). Changes in gill morphology, subsequently leading to disruption in oxygen consumption, are found to be early warnings for endosulfan stress in fish (Altinok and Capkin, 2007).

\section{MATERIALS AND METHODS}

Fishes of similar length (Standard Length: $46.77 \pm 4.30 \mathrm{~mm})$ and weight $(0.86 \pm 0.16 \mathrm{~g})$ were collected from a freshwater pond near Assam University campus, Barak valley, South Assam,

*Corresponding author's email: drsuchismita9@gmail.com 
India. The age of the fish was not known but mature fish were collected. They were acclimatized under laboratory conditions for seven days prior to experimentation in tap water that was stored overnight and aerated, and fed with commercially available fish food twice a day. Temperature, dissolved oxygen, hardness and $\mathrm{pH}$ of water were maintained under laboratory conditions at $29 \pm 0.13{ }^{\circ} \mathrm{C}, 5.5 \pm 0.24$ $\mathrm{mgl}^{-1}, 30 \pm 0.5 \mathrm{mgl}^{-1}$ and $6.8 \pm 0.03$, respectively. A stock solution of commercial grade endosulfan $(6,7,8,9,10,10$-hexachloro-1,5,5a,6,9,9a-

hexahydro-6,9-methano-2,3,4-

benzodioxathiepin-3-oxide)

(Thiodanendosulfan 35\% EC, Bayer Crop Science, India) was prepared using double distilled water. Serial dilutions of the stock solution were prepared using previously aerated and stored tap water. Three sub-lethal test concentrations viz., 0.49, 0.049 and $0.0049{\mu \mathrm{gl}^{-1}}$ were selected (1/10th, $1 / 100^{\text {th }}$ and $1 / 1000^{\text {th }}$ of $96 \mathrm{~h} \mathrm{LC}_{50}$ value) for studying the effects on rates of oxygen consumption and gill morphology. Ethical guidelines from the Canadian Council on Animal Care were followed that include the following: fishes were maintained in properly aerated aquaria in a quiet and well-ventilated room, crowding was avoided; an adequate amount of nutritious food was provided; fishes were handled gently and only when necessary; aquaria were covered with nets as E. danricus has the habit of jumping out and suffer mortality (CCAC, 2005).

Three test chambers (each of 3 litre in capacity) were marked A, B and C containing 0.49, 0.049 and $0.0049 \mu \mathrm{g} \mathrm{l}^{-1}$ of endosulfan respectively. Each test chamber contained ten fish. At the end of exposure for 7 days, each fish of test chamber A was transferred to the respiratory chamber, which was also numbered in accordance with the test chamber and the experiment was run for a period of one hour (modified after Susan and Sobha, 2010). After the experiment, each fish was weighed and placed in its respective test chamber. The same process was repeated for other fishes of the test chamber A (ten replicates) and for 14, 21 and 28 days. The test water containing pesticide was renewed every 24 hours during the study period. Controls were also run simultaneously in tap water to obtain information on the normal rates of oxygen consumption of the fish. Similarly, the process was repeated for the fish in test chambers B and C. Respiratory measurements were made using a closed chamber method (Fitch, 1975) and the dissolved oxygen was estimated by the Winkler method (Hoar and Hickman, 1967). The amount of oxygen consumed by the fish was expressed in $\mathrm{ml} / \mathrm{hr} / 100 \mathrm{~g}$ of tissue.

Statistical significance of the differences in oxygen consumption between control and exposed fish at different endosulfan concentrations were made by 2-way ANOVA at $\mathrm{p}<0.05$ and dose-response dependency was tested by the Pearson correlation co-efficient (r) using SYSTAT 13 software for Windows.

\section{Histological examinations}

Ten fishes were kept for 28 days in three litres of test solution containing sub-lethal test concentrations of $0.49,0.049$ and $0.0049 \mu \mathrm{gl}^{-1}$ endosulfan. Fish were fed twice a day during the study period. Water was renewed every 24 hours. After 28 days of exposure, fish were scarified and, gills were removed immediately and fixed in $10 \%$ formalin for 24 hours, dehydrated and embedded in paraffin. Sections of $5 \mu \mathrm{m}$ thickness were taken and stained with Harris haematoxylin and Eosin. Changes induced by endosulfan in the gill as well as control gills were photographed and examined under a light microscope at a magnification of 10×40 (Olympus model U-CMAD3 with camera attachment Samsung model SDC-313B).

\section{RESULTS}

The average rate of oxygen consumption in control fish after 28 days was found to be $39.06 \pm 0.146 \mathrm{ml} / \mathrm{hr} / 100 \mathrm{~g}$ tissue). Rates of oxygen consumption after exposure to 0.49 , 0.049 and $0.0049 \mu \mathrm{g} \mathrm{l}^{-1}$ of endosulfan after 28 days were $10.95,14.85$ and $19.67 \mathrm{ml} / \mathrm{hr} / 100 \mathrm{~g}$ tissue, respectively. A significant negative doseresponse of endosulfan was obtained. With increasing exposure duration, there was a corresponding decrease in the oxygen consumption up to day 28 (Table 1).

The gill of the Indian flying barb is made up of double rows of filaments from which lamellae arise perpendicularly (Fig. 1a). Endosulfan exposure caused mucus secretion, epithelial lifting, lamellar fusion and hypertrophy (Figs. $1 \mathrm{~b}, 1 \mathrm{c}$ and $1 \mathrm{~d}$ ), and the degree of damage ranged from mild to severe with increasing exposure. In addition, lamellar blood sinus constriction was observed only in 0.049 and $0.49 \mu \mathrm{g} \mathrm{l^{-1 }}$ of endosulfan exposure (Figs. 1c and 1d), while the highest sublethal dose $\left(0.49 \mu \mathrm{g} \mathrm{l}^{\mathbf{- 1}}\right)$ of endosulfan showed profuse mucous cell proliferation and vascular congestion (Fig. 1d). 

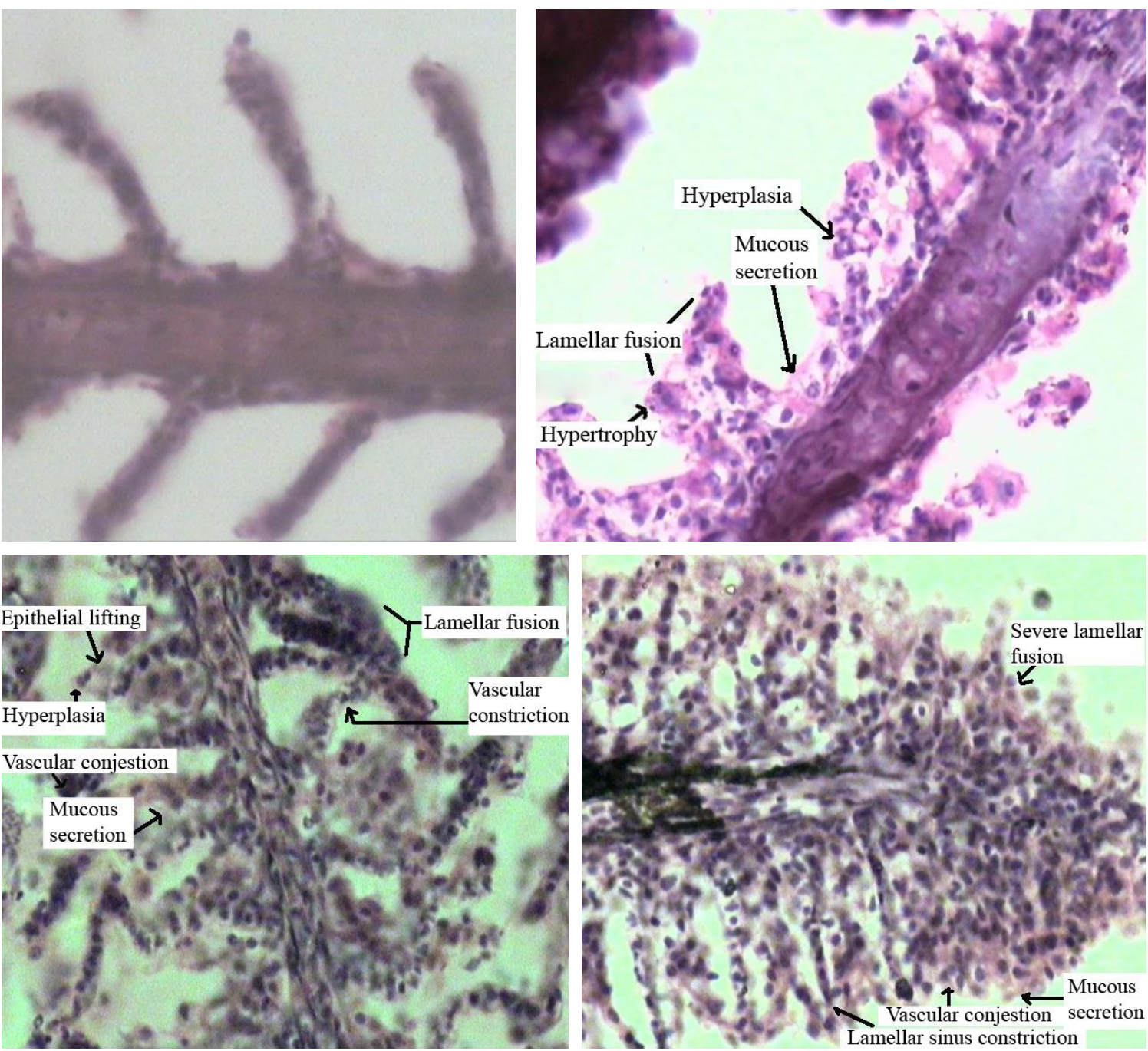

Figure 1. T.S of gills of fish (10x40 magnification) (a) in the control group, showing normal gill architecture (b) fish exposed to $0.0049 \mu \mathrm{gL}^{-1}$ endosulfan for 28 days, showing lamellar fusion, mucus secretion, hyperplasia and hypertrophy (c) fish exposed to $0.049 \mu \mathrm{gL}^{-1}$ endosulfan for 28 days showing lifting of epithelium, mucus secretion, lamellar fusion, hyperplasia vascular constriction and congestion and (d) fish exposed to $0.49 \mu \mathrm{gL}^{-1}$ endosulfan for 28 days, showing lifting of epithelium, mucus secretion, lamellar fusion, vascular congestion and lamellar sinus constriction.

Table 1. Mean rate of oxygen consumption in Esomus danricus at different endosulfan (EC 35) concentrations and at different time periods with standard error of mean values

\begin{tabular}{|c|c|c|c|c|c|}
\hline Endosulfan $\left(\mu \mathrm{gl}^{-1}\right)$ & \multicolumn{3}{|c|}{ Oxygen consumption ( $\mathrm{ml} / \mathrm{hr} / 100 \mathrm{~g}$ tissue) } & \multirow[b]{2}{*}{21 days } & \multirow[b]{2}{*}{28 days } \\
\hline & 0 day & 7 days & 14 days & & \\
\hline 0 (Control) & $38.57 \pm 0.051$ & $38.94 \pm 0.146$ & $39.19 \pm 0.094$ & $39.03 \pm 0.077$ & $39.06 \pm 0.049$ \\
\hline 0.0049 & $38.51 \pm 0.12$ & $32.69 \pm 0.764 *$ & $28.74 \pm 0.91 *$ & $24.51 \pm 0.91 *$ & $19.67 \pm 0.879 *$ \\
\hline 0.049 & $38.65 \pm 0.541$ & $27.75 \pm 0.849 *$ & $21.81 \pm 1.09 *$ & $17.91 \pm 1.03 *$ & $14.85 \pm 1.05^{*}$ \\
\hline 0.49 & $38.6 \pm 0.153$ & $20.85 \pm 0.86 *$ & $17.96 \pm 0.696^{*}$ & $15.85 \pm 0.607 *$ & $10.95 \pm 0.725^{*}$ \\
\hline $\mathrm{r}$ & & -0.805 & -0.671 & -0.581 & -0.584 \\
\hline
\end{tabular}

* Significance at $\mathrm{p}<0.05$; 'r' = Correlation Co-efficient 


\section{DISCUSSION}

Respiratory distress is one of the early symptoms of pesticide poisoning (Murthy, 1986). The depression in respiratory rates is possibly by alteration of energy metabolism (Olsen et al., 2005). The experimental data of the present study reveals that oxygen consumption decreases with the time of exposure to the tested toxicant and is well supported by Pillai and Diwan (2002). Rao (1991) studied the oxygen consumption rate of the bivalve mollusc Mytilopsis sallei to endosulfan at different concentrations of sea water for exposure periods of 24, 48, 72 and 96 hours. He reported an increase in oxygen consumption up to 24 hours, which later declined gradually at 48, 72 and 96 hours. This initial increase is probably a response to the sudden onset of toxicity that led to acceleration of oxidative metabolism. However, prolonged exposure to toxicants, as was done in the present study, had altered gill morphology, which in turn depressed the oxygen consumption resulting in asphyxia (Barbieri et al., 2002). The decreased oxygen consumption in endosulfan-exposed fish is likely due to the absorbance of a greater amount of pesticide through the gills which are in direct contact with the toxic test medium. A similar reduction in oxygen consumption due to endosulfan has been reported in the freshwater crab Trichodactylus borellianus (Montagna and Collins, 2008) and the teleost fish Macrognathus aculeatum (Rao et al., 1981).

Changes in fish gills are among the most commonly recognized responses to environmental pollutants (Au, 2004). The teleost fish gill is covered by a complex epithelium. The gill epithelium is the dominant site of gas exchange, ionic regulation, acid-base balance, and nitrogenous waste excretion (Hoar and Randall, 1984). In the present study, histopathology revealed marked alterations in gill structure of the fishes exposed to endosulfan, including hyperplasia with lamellar fusion, epithelial hypertrophy, epithelial lifting, mucous secretion, mucous cell proliferation, vascular congestion and blood sinus constriction. The lifting of the lamellar epithelium of the gill in $E$. danricus, observed in the present investigation, serves as a mechanism of defence, because separation of epithelia from the lamellae increases the distance across which waterborne pollutants must diffuse to reach the bloodstream (Pane et al., 2004). Cell proliferation with thickening of the gill filament epithelium is another histological change seen in the present study. The proliferated thickening (hyperplasia) of the gill epithelium, observed when exposed to $0.049 \mathrm{\mu gl}^{-1}$ of endosulfan, appears to be a general response to irritation by toxicants. Such types of thickening of gill filament epithelium may lead to lamellar fusion on exposure to all the sublethal doses of endosulfan. Lamellar fusion is a defence mechanism that reduces the branchial superficial area in contact with the external milieu and increases the diffusion barrier to the pollutant (De Boeck et al., 2001). Similar information of thickening of gill filament epithelium in fish was reported by several authors including Cengiz and Unlu, (2002), Van den Heuvel et al., (2000), Van Heerden et al., (2004) and Rosety-Rodríguez et al., (2002). In this study, all the sublethal doses of endosulfan induced excessive mucus secretion in gills. This phenomenon of mucus secretion can also impair gas exchange across the secondary lamellae epithelium, also seen in endosulfan exposed rainbow trout by Altinok and Capkin (2007) and disrupt the osmoregulatory function of fish (Saravana and Geraldine, 2000). Thus, it is clear from this study that endosulfan, even at sublethal doses, injures gills, reducing the rate of oxygen consumption in the Indian flying barb.

\section{REFERENCES}

Altinok, I. and Capkin, E. (2007). Histopathology of Rainbow Trout Exposed to Sublethal Concentrations of Methiocarb or Endosulfan. Toxicologic Pathology 35: 405410.

Au, D.W.T. (2004). The application of histocytopathological biomarkers in marine pollution monitoring: a review. Marine Pollution Bulletin 48: 817-834.

Barbieri, E. (2007). The use of active metabolism and swimming activity to evaluate the toxicity of dodecyl benzene sodium sulfonate (LAS-C12) on the Mugil platanus (Mullet) according to temperature and salinity. Water Environment Research 79: 707-719.

Barbieri, E., Serralheiro, P.C. and Rocha, I.O. (2002). The use of metabolism to evaluate the toxicity of dodecil benzen sodium sulfonate (LAS-C12) on the Mugil platanus (mullet) according to the temperature and salinity. Journal of Experimental Marine Biology and Ecology 277: 109-127. 
Berril, M., Bertram, S., McGillivary, L., Kolohon , M. and Pauli, B. (1994). Effects of low concentrations of forest-use pesticides on frog embryos and tadpoles. Environment Toxicology and Chemistry 13: 657-664.

Capkin, E., Altinok, I., and Karahan, S. (2005).Water quality and fish size affect toxicity of endosulfan, an organochlorine pesticide, to rainbow trout. Chemosphere 64: 1793-1800.

CCAC (2005). CCAC Guidelines on: the Care and Use of Fish in Research, Teaching and Testing. Canadian Council on Animal Care. http://www.ccac.ca/Documents/Standa rds/Guidelines/Fish.pdf (19 December 2012).

Cengiz, E.I. and Unlu, E. (2002). Histopathological Changes in the Gills of Mosquito fish, Gambusia affinis Exposed to Endosulfan. Environmental contamination and toxicology 68: 290-296.

Das, S. and Gupta, A. (2012). Effects of Cadmium Chloride on oxygen consumption and gill morphology of Indian flying barb, a teleost fish, Esomus danricus. Journal of Environmental Biology 33: 1057-1061.

De Boeck, G., Vlaeminck, A., Balm, P.H., Lock, R.A., De Wachter, B. and Blust, R. (2001). Morphological and metabolic changes in common carp, Cyprinus carpio, during shortterm copper exposure: interactions between $\mathrm{Cu}^{2+}$ and plasma cortisol elevation. Environment Toxicology and Chemistry 20: 374-381.

Devi, R. and Boguskaya, N. (2009). Esomus danrica. In: IUCN 2012. IUCN Red List of Threatened Species. Version 2012.2. www.iucnredlist.org. (21 December 2012).

Fitch, D.D. (1975). Oxygen consumption in the Prosobranch snail, Viviparous contectoides (Mollusca: Gastropoda) - Effects of weight and activity. Comparative Biochemistry and Physiology Part A 51: 815-820.

Gurusubramanian, G., Rahman, A., Sarmah, M., Ray, S. and Bora, S. (2008). Pesticide usage pattern in tea ecosystem, their retrospects and alternative measures. Journal of Environmental Biology 29: 813-826.

Hoar, W.S. and Hickman, C.P. Jr. (1967). A laboratory comparasion for general and comparative physiology, Prentice-Hall, Englewood Cliffs, NJ. pp-286-289.

Hoar, W.S. and Randall, D.J. (1984). Fish physiology. Vols. X, B, Academic Press, Orlando.

Montagna, M.C. and Collins, P.A. (2008). Oxygen consumption and ammonia excretion of the freshwater crab Trichodactylus borellianus exposed to chlorpyrifos and endosulfan insecticides. Pesticide Biochemistry and Physiology 92: 150-155.

Murty, A. S. (1986). Pesticides in the Environment. In: Toxicity of Pesticides to Fish, Vol. I and II, CRC press, Boca Raton, FL, U.S.A. pp 1-36.

Olsen, R.E., Sundell, K., Mayhew, T.M., Myklebust, R. and Ring, E. (2005). Acute stress alters intestinal function of rainbow trout, Oncorhynchus mykiss (Walbaum). Aquaculture 250: 480-495.

Pane, E.F., Haque, A. and Wood, C.M. (2004). Mechanistic analysis of acute Ni-induced respiratory toxicity in the rainbow trout (Oncorhynchus mykiss): an exclusively branchial phenomenon. Aquatic Toxicology 69: 11-24.

Pillai, B.R. and Diwan, A.D. (2002). Effects of acute salinity stress on oxygen consumption and ammonia excretion rates of the marine shrimp Metapenaeus monoceros. Journal of Crustacean Biology 22: 45-52.

Rao, D.M.R., Devi, A.P. and Murty, A.S. (1980). Relative toxicity of endosulfan, its isomers, and formulated products to the freshwater fish Labeo rohita. Journal of Toxicology and Environmental Health 6: 825-834.

Rao, D.M.R., Devi, A.P. and Murty, A.S. (1981).Toxicity and metabolism of endosulfan and its effect on oxygen consumption and total nitrogen excretion of the fish Macrognathus aculeatum. Pesticide Biochemistry and Physiology 15: 282-287.

Rao, J.M. (1991). Effect of salinity and the pesticide Endosulfan on the physiology of Mytillopsis sallei [PhD thesis].Waltair, India: Andhra University.

Romeo, F. and Quijano, M.D. (2000). Risk assessment in a third world reality: An endosulfan case history. International Journal of Occupational and Environmental Health 6: 312-317.

Rosety-Rodríguez, M., Ordoñez, F.J., Rosety, J.M., Rosety, I., Ribelles, A. and Carrasco, C. (2002). Morpho-histochemical changes in the gills of turbot, Scophthalmus maximus L., induced by sodium dodecyl sulfate. Ecotoxicology and Environmental Safety 51: 223-228.

Samad, M.A., Asaduzzaman, M., Galib, S.M., Kamal, M.M. and Haque, M.R. (2010). Availability and consumer preference of small indigenous species (SIS) of the river Padma at Rajshahi, Bangladesh. International Journal of BioResearch 1: 2731. 
Saravana, B.P. and Geraldine, P. (2000). Histopathology of the hepatopancreas and gills of the prawn Macrobrachium malcolmsonii exposed to endosulfan. Aquatic Toxicology 50: 331-339.

Schwaiger, J., Ferling, H., Mallow, U., Wintermayr, H. and Negele, R.D. (2004). Toxic effects of the non-steroidal antiinflammatory drug diclofenac. Part I. Histopathological alterations and bioaccumulation in rainbow trout. Aquatic Toxicology 68: 141-150.

Shivakumar, R. and David, M. (2004). Toxicity of endosulfan to the freshwater fish, Cyprinus carpio. Indian Journal of Ecology 31: 27-29.

Susan, T.A. and Sobha, K. (2010). A study on acute toxicity, oxygen consumption and behavioural changes in the three major Carps, Labeo rohita (ham), Catla catla (ham) and Cirrhinus mrigala (ham) exposed to Fenvalerate. Bioresearch Bulletin 1: 3340.

Thangavel, P., Sumathiral, K., Maheswari, S., Rita, S. and Ramaswamy, M. (2010). Hormone profile of an edible, freshwater teleost, Sarotherodon mossambicus (Peters) under endosulfan toxicity. Pesticide Biochemistry and Physiology 97: 229-234.

Tripathi, G. and Verma, P. (2004). Endosulfanmediated biochemical changes in the freshwater fish Clarias batrachus. Biomedical Environment Science 17:47-56.

Van den Heuvel, M.R., Power, M., Richards, J., MacKinnon, M. and Dixon, D.G. (2000). Disease and gill lesions in yellow perch (Perca flavescens) exposed to oil sands mining-associated water. Ecotoxicology and Environmental Safety 46: 334-341.

Van Heerden, D., Vosloo, A. and Nikinmaa, M. (2004). Effects of short-term copper exposure on gill structure, metallothionein and hypoxia-inducible factor-1 (HIF-1) levels in rainbow trout (Oncorhynchus mykiss). Aquatic Toxicology 69: 271-280.

Vutukuru, S.S., Suma, Ch. K., Madhavi, K. R., Juveria, K., Pauleena, J.S., Rao, J.V., and Anjaneyulu, Y. (2005). Studies on the Development of Potential Biomarkers for Rapid Assessment of Copper Toxicity to Freshwater Fish using Esomus danricus as Model. International Journal of Environmental Research and Public Health 2: 63-73. 